\title{
A Survey of Trunk Disease Pathogens within Citrus Trees in Iran
}

\author{
Nahid Espargham ${ }^{1}$, Hamid Mohammadi ${ }^{1, *(\mathbb{D})}$ and David Gramaje ${ }^{2, *(\mathbb{D}}$ \\ 1 Department of Plant Protection, Faculty of Agriculture, Shahid Bahonar University of Kerman, \\ Kerman 7616914111, Iran; hmho279@yahoo.com \\ 2 Instituto de Ciencias de la Vid y del Vino (ICVV), Consejo Superior de Investigaciones Científicas, \\ Universidad de la Rioja, Gobierno de La Rioja, 26007 Logroño, Spain \\ * Correspondence: hmohammadi@uk.ac.ir (H.M.); david.gramaje@icvv.es (D.G.); \\ Tel.: +98-34-3132-2682 (H.M.); +34-94-1899-4980 (D.G.)
}

Received: 4 May 2020; Accepted: 12 June 2020; Published: 16 June 2020

\begin{abstract}
Citrus trees with cankers and dieback symptoms were observed in Bushehr (Bushehr province, Iran). Isolations were made from diseased cankers and branches. Recovered fungal isolates were identified using cultural and morphological characteristics, as well as comparisons of DNA sequence data of the nuclear ribosomal DNA-internal transcribed spacer region, translation elongation factor $1 \alpha, \beta$-tubulin, and actin gene regions. Dothiorella viticola, Lasiodiplodia theobromae, Neoscytalidium hyalinum, Phaeoacremonium (P.) parasiticum, P. italicum, P. iranianum, P. rubrigenum, P. minimum, P. croatiense, P. fraxinopensylvanicum, Phaeoacremonium sp., Cadophora luteo-olivacea, Biscogniauxia (B.) mediterranea, Colletotrichum gloeosporioides, C. boninense, Peyronellaea (Pa.) pinodella, Stilbocrea (S.) walteri, and several isolates of Phoma, Pestalotiopsis, and Fusarium species were obtained from diseased trees. The pathogenicity tests were conducted by artificial inoculation of excised shoots of healthy acid lime trees (Citrus aurantifolia) under controlled conditions. Lasiodiplodia theobromae was the most virulent and caused the longest lesions within 40 days of inoculation. According to literature reviews, this is the first report of L. theobromae and N. hyalinum on citrus in Iran. Additionally, we report several Phaeoacremonium species, S. walteri, Pa. pinodella and C. luteo-olivacea on citrus trees for the first time in the world.
\end{abstract}

Keywords: bscogniauxia; botryosphaeriaceae; cadophora; citrus dieback; colletotrichum; phaeoacremonium

\section{Introduction}

Iran is the sixth largest Citrus producer, accounting for $3.3 \%$ of the world's Citrus production, which yielded 4.1 million tons in 2016 [1]. A total of 276,000 ha of various Citrus species are cultivated in Iran, including sweet orange (Citrus sinensis L.), acid lime (C. aurantifolia (Christm.) Swingle), sour orange (C. aurantium L.), mandarin (C. reticulata Blanco), lemon (C. limon (L.) Osbeck), and grapefruit (C. paradisi Macfad). The most important producing regions in Iran are Mazandaran, Fars, Hormozgan, Giroft, and Kahnouj.

Fungal trunk diseases have been studied in detail in grapevine, which are the main biotic factor limiting vineyard productivity and longevity [2]. However, recent findings of high incidence in stone and pome fruits, small fruits, nut crops, citrus, and olive worldwide highlight the need for a focus on this novel group of hosts [3]. Trunk diseases are caused by a broad range of taxonomically unrelated fungi that primarily infect wood hosts through winter pruning wounds, thus colonizing the vascular tissues. Members of the families Botryosphaeriaceae, Togninaceae, Diatrypaceae, Diaporthaceae, as well as several basidiomycetes are included in this group of fungi. Members of Diatrypaceae 
(Xylariales) can often be observed on dead wood and bark of a wide range of plant species around the world. Nevertheless, some species of this family are reported as putative plant pathogens on fruit, ornamental, and forest trees [4-8]. Some species of Eutypella have been previously isolated from citrus species, including Citrus limon, C. paradisi, C. maxima, and C. aurantium in Australia, Argentina, Brazil, Coted'Ivoire, Philippines, and USA [9-14]. Diatrypaceae spp. were also isolated from citrus trees in Australia [15].

Species of Botryosphaeriaceae have a cosmopolitan distribution and have been associated with numerous plant species worldwide [16-18]. Many species of the genera Lasiodiplodia [19-23], Diplodia, Dothiorella, Neofusicoccum [20], and Neoscytalidium [14,20] have been previously reported to affect citrus trees. Togniniaceae (Togniniales), with the well-known asexual morph genus Phaeoacremonium, is another family of fungi traditionally associated with dieback, canker, and yellowing of various fruit, forest, and ornamental trees, worldwide [24-31]. To date, 56 Phaeoacremonium species have been identified from woody hosts [32]. The most prevalent Phaeoacremonium species isolated from woody hosts are P. minimum, followed by P. parasiticum [33]. Dieback and related disease symptoms have been achieved by inoculating Phaeoacremonium species onto several hosts such as Prunus spp., kiwifruit, oak, and grapevine [33,34]. Phaeoacremonium species isolated from grapevine have been intensively studied because of their involvement in two trunk diseases, Petri disease in young vines and esca in mature vines [32,35]. To our knowledge, there are no reports of Phaeoacremonium species affecting Citrus spp.

In spring 2014, a severe decline of citrus trees was noticed in some orchards in Bushehr (Bushehr province, Iran). External disease symptoms included chlorosis of leaves, defoliation, branch and shoot cankers, and dieback. Internal wood symptoms ranged from brown to black wood streaking and black spots to wedge-shaped necrosis, irregular wood discoloration, central necrosis, and arch-shaped necrosis. Many fungi associated with trunk diseases have been isolated from several woody hosts in Iran, including grapevine [36,37], pome and stone fruit trees [28,38], and ornamental and forest trees $[29,31,39,40]$. However, little information is presently available on the causal agents of the severe decline of citrus trees in Iran. Therefore, the aim of this study was to investigate the etiology of fungal trunk diseases associated with wood necrosis of citrus trees in Iran and to determine their pathogenicity.

\section{Results}

\subsection{Field Survey and Diversity of Disease Symptoms}

In this study, wood samples were collected from lime (46 trees), sweet lemon (23 trees), sweet orange (22 trees), mandarin (eight trees), sour orange (four trees) and lemon (three trees). Citrus trees showed various external disease symptoms, including yellowing, canker, defoliation, dieback, cracking of the bark associated with gumming, and sooty cankers (form a black powder underneath the bark). Examination of infected branches from symptomatic trees revealed different types of wood discoloration in cross-sections, black to brown streaking in the wood, wedge-shaped necrosis, black spots, irregular wood discoloration, central necrosis, and arch-shaped necrosis (Figure 1). 

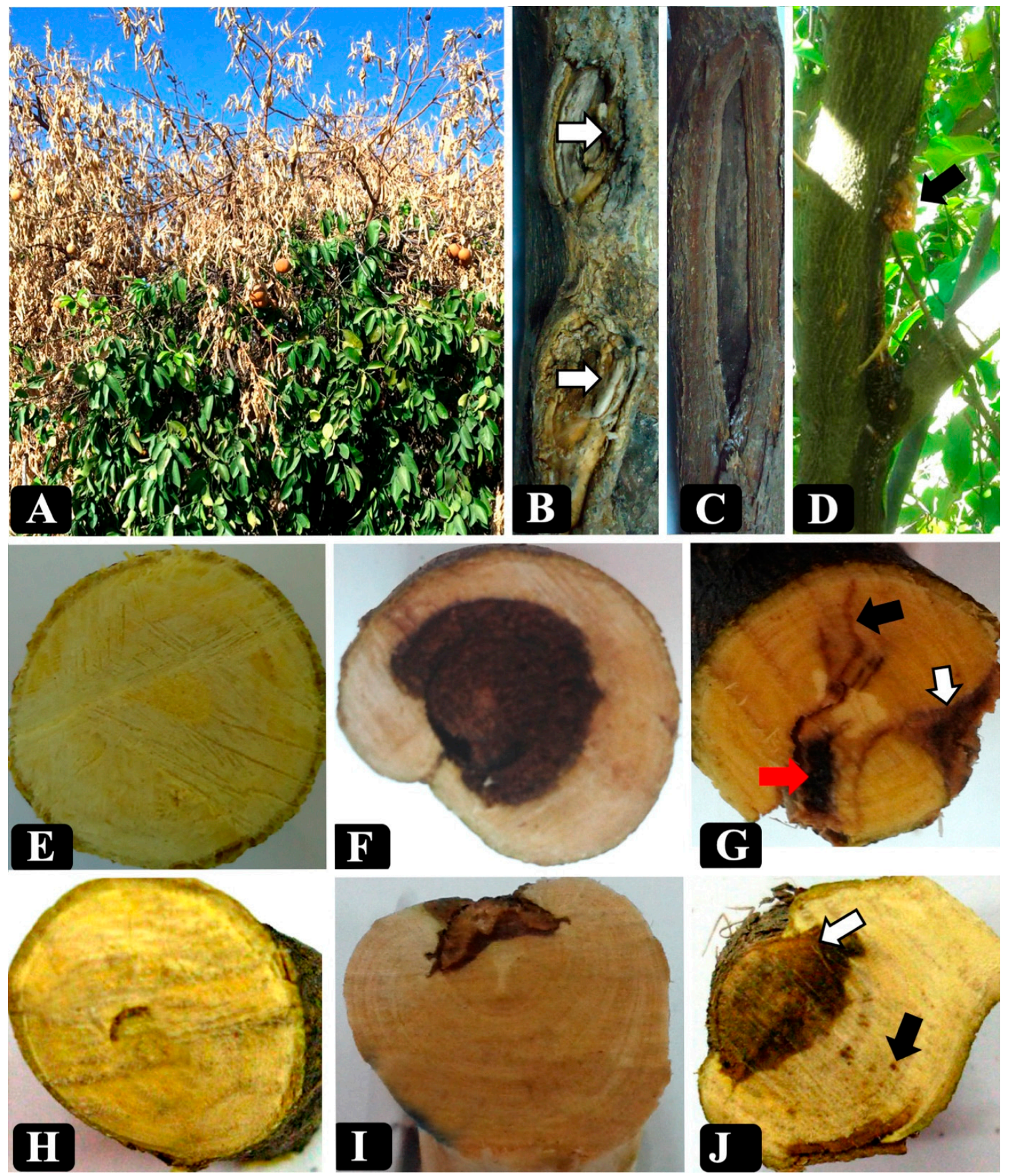

Figure 1. Diversity of external (A-D) and internal (E-I) trunk disease symptoms on Citrus species in Iran (A) a severe dieback on Citrus sinensis; (B) two cankers on a trunk of a C. sinensis tree indicated by arrows; (C) an extended canker on the branch of Citrus aurantifolia indicated by arrow; (D) gummosis on Citrus limetta; (E) cross-section of a healthy branch of C. aurantifolia; (F) central necrosis on C. sinensis; (G) Co-occurrence of brown wood streaking (black arrow), wedge-shaped necrosis (white arrow) and irregular wood necrosis (red arrow) on C. sinensis; $(\mathbf{H})$ Arch-shaped necrosis on C. aurantifolia; (I) a young wedge shaped necrosis on Citrus reticulata; ( $\mathrm{J}$ ) Co-occurrence of wedge-shaped necrosis is indicated by the white arrow and black spots are indicated by the black arrow on the C. sinensis. 


\subsection{Fungal Isolation and Morphological Identification}

In this survey, 326 fungal isolates were collected from citrus trees (Table 1). According to colony appearance, culture characteristics, and microscopic structures, the main fungal isolates were classified as Phaeoacremonium spp., Botryosphaeriaceae spp. Cadophora sp., Colletotrichum spp., Peyronellaea sp., Phoma spp., and Biscogniauxia mediterranea. Thirty-nine isolates (11.96\% of total isolates) were identified as Phaeoacremonium species and characterized by beige to medium brown flat slow-growing cultures on potato dextrose agar (PDA; Merck, Darmstadt, Germany) and on malt extract agar (MEA; $2 \%$ malt extract, Merck, Darmstadt, Germany). Septate hyphae were single or fasciculate, and three types of phialides, variable in shape and size (I, II, and III types), were recorded in these isolates [41]. Morphological features of 49 isolates (15.03\%) were consistent with the description of species of Botryosphaeriaceae $[16,17,42]$. These isolates were characterized by dark green to gray or fast-growing gray mycelium on the PDA. All isolates produced fruit bodies, pycnidia, on pine needles within 15-35 days. Conidia were pigmented or hyaline. These isolates belonged to the genera Lasiodiplodia, Neoscytalidium, and Dothiorella. Twelve isolates of the phialides fungus were identified as Cadophora sp. These isolates formed flat, felty, and black-olivaceous and white to gray colonies on PDA, and their conidia were ellipsoid or elongate. Cultural and morphological characteristics observed were similar with the description of the Cadophora spp. [43,44]. Based on morphological characteristics, the remaining isolates were classified to Colletotrichum, Peyronellea, Pestalotiopsis, Fusarium, Microsphaeropsis, Alternaria, Trichoderma, Paecilomyces, Aspergillus, Penicillium, Phoma, Biscogniauxia, and Stilbocrea genera.

Table 1. Fungal species isolated from Citrus species in Iran.

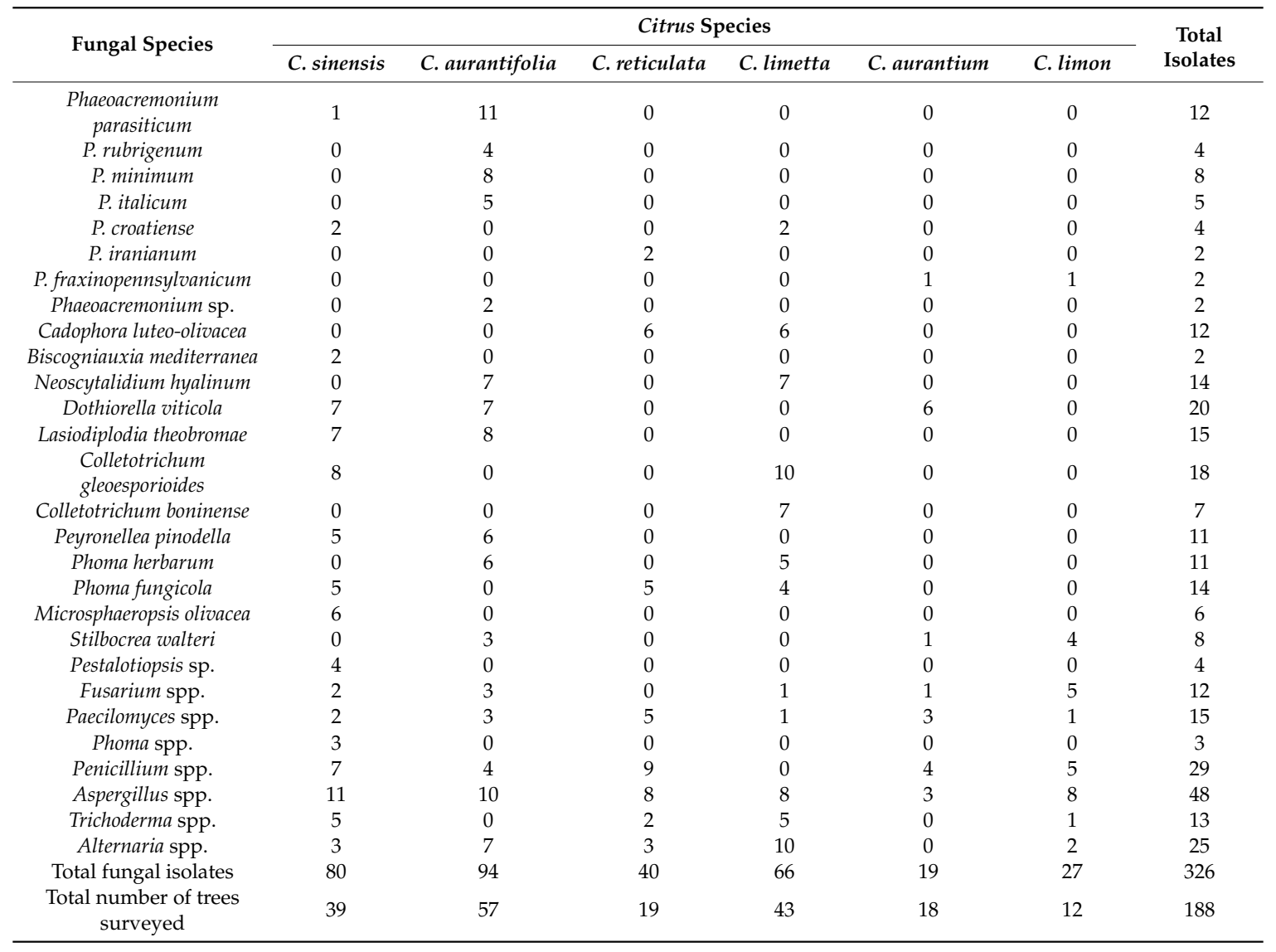


No association was found between wood symptoms and fungal species. Dual infections by trunk disease fungi in a single tree occurred. Phaeoacremonium parasiticum and P. italicum were isolated from one tree of C. aurantifolia; P. parasiticum, P. croatiense, and Do. viticola from one tree of C. sinensis, L. theobromae and Neoscytalidium hyalinum from one tree of C. aurantifolia, and C. luteo-olivacea and $P$. croatiense from one tree of $C$. limetta. In addition, some fungal species grew from an individual wood segment, such as Stilbocrea walteri and P. fraxinopennsylvanicum from C. limon.

\subsection{Molecular Characterization and Phylogenetic Analyses}

BLASTn searches in GenBank showed that the nuclear ribosomal DNA-internal transcribed spacer region (ITS) and translation elongation factor $1 \alpha$ (tef1- $\alpha$ ) sequences of Botryosphaeriaceae isolates had 99-100\% identity with isolates of Lasiodiplodia theobromae (strain CBS559.70), Neoscytalidium hyalinum (strain CBS 145.78), and Dothiorella viticola (strain CBS 117006). The ITS sequences of the Cadophora isolates had $99-100 \%$ identity with isolates previously identified as Cadophora luteo-olivacea in GenBank (strain CBS 855.69). ITS and $\beta$-tubulin (BT) sequences of Colletotrichum isolates were identical to isolates previously reported as Colletotrichum gloeosporioides (ITS: strain CBS 132465; BT: strain CBS 100471) and Colletotrichum boninense (ITS and BT: strain CBS:123755) in GenBank. ITS and BT sequences of Peyronellea isolates in our study showed $99-100 \%$ identity with those isolates previously submitted as Didymella pinodella (strain CBS 531.66) in GenBank. ITS and tef1- $\alpha$ sequences of Stilbocrea isolates from citrus trees had 99-100\% identity with Stilbocrea walteri (strain NQI). Regarding the Biscogniauxia isolates, ITS of our isolates had $99-100 \%$ identity with isolates previously identified as Biscogniauxia mediterranea (strain CBS 129072).

Datasets of the BT and actin (ACT) alignments of Phaeoacremonium were congruent and could be combined ( $p=0.225)$. The Hasegawa-Kishino-Yano model (HKY) with gamma distributed with invariant sites rates $(\mathrm{G}+\mathrm{I})$ was identified as the BIC best-fit nucleotide substitution model by the jModelTest for the Phaeoacremonium multi-locus analysis. Maximum likelihood (ML) of the combined ACT-BT regions provided a phylogeny with 98 to $100 \%$ ML bootstrap support for all species-level clades, with the exception of $P$. alvesii (paraphyletic, $87 \%$ bootstrap support), $P$. griseorubrum (paraphyletic, $66 \%$ bootstrap support), P. roseum ( $89 \%$ bootstrap support), and P. viticola (paraphyletic with regard to P. roseum and P. angustius) (Figure 2). The 39 strains from Iran clustered in eight clades (P. italicum, Phaeoacremonium sp., P. rubrigenum, P. parasiticum, P. minimum, P. iranianum, P. fraxynopennsylvanicum, and P. croatiense). The isolates of the clade 2 grouped together in a polyphyletic clade with $100 \%$ bootstrap support with the P. italicum as a closely related species. The BT and ACT sequences of the second clade of Phaeoacremonium isolates were $98 \%$ (BT) and $98.77 \%$ (ACT) identical to those of P. italicum CBS 137763 (GenBank KJ534074, KJ534046). Three nucleotides varied in the ACT region and ten nucleotides in the BT region between the second clade of Phaeoacremonium isolates and the P. italicum CBS 137763 sequences. 


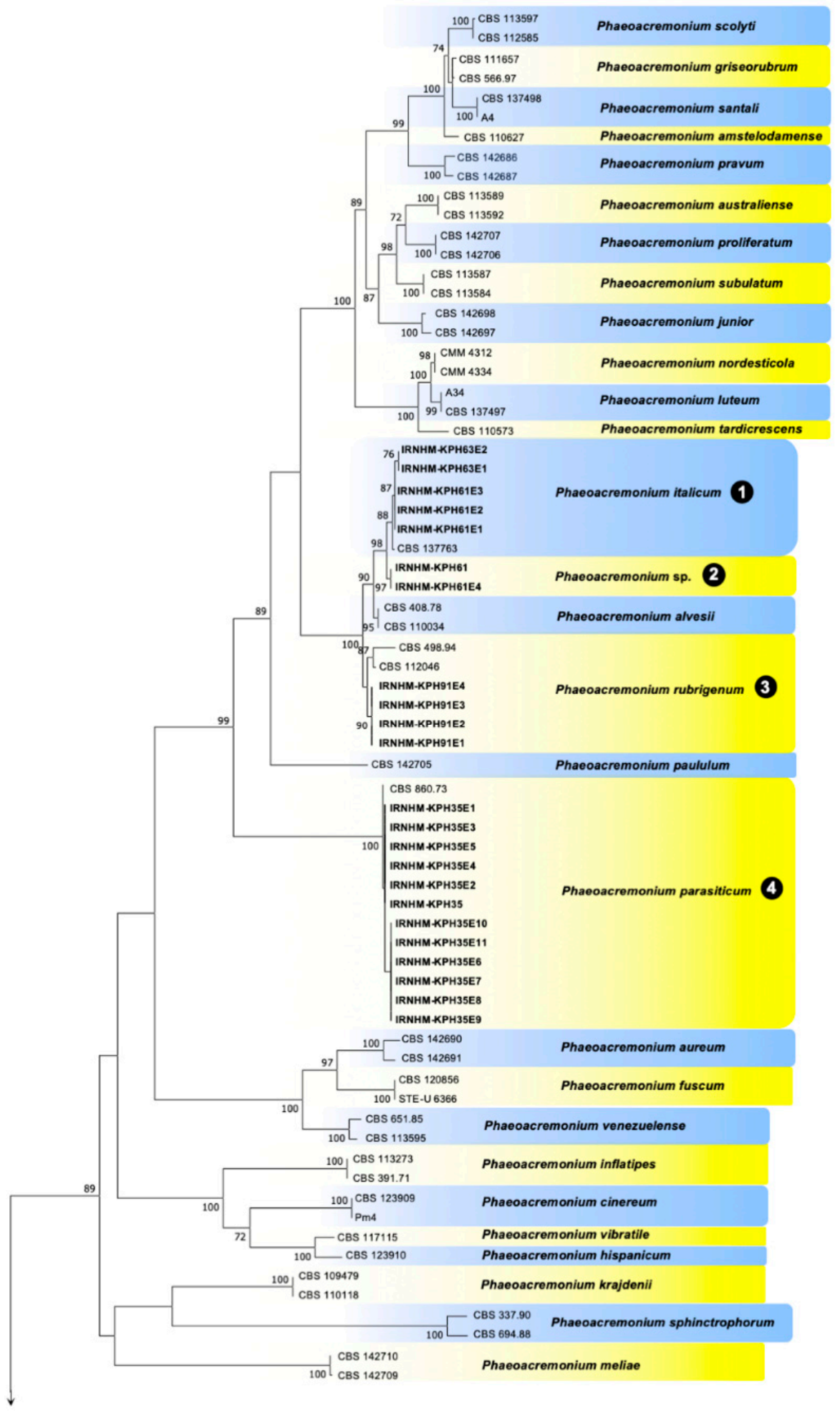

Figure 2. Cont. 


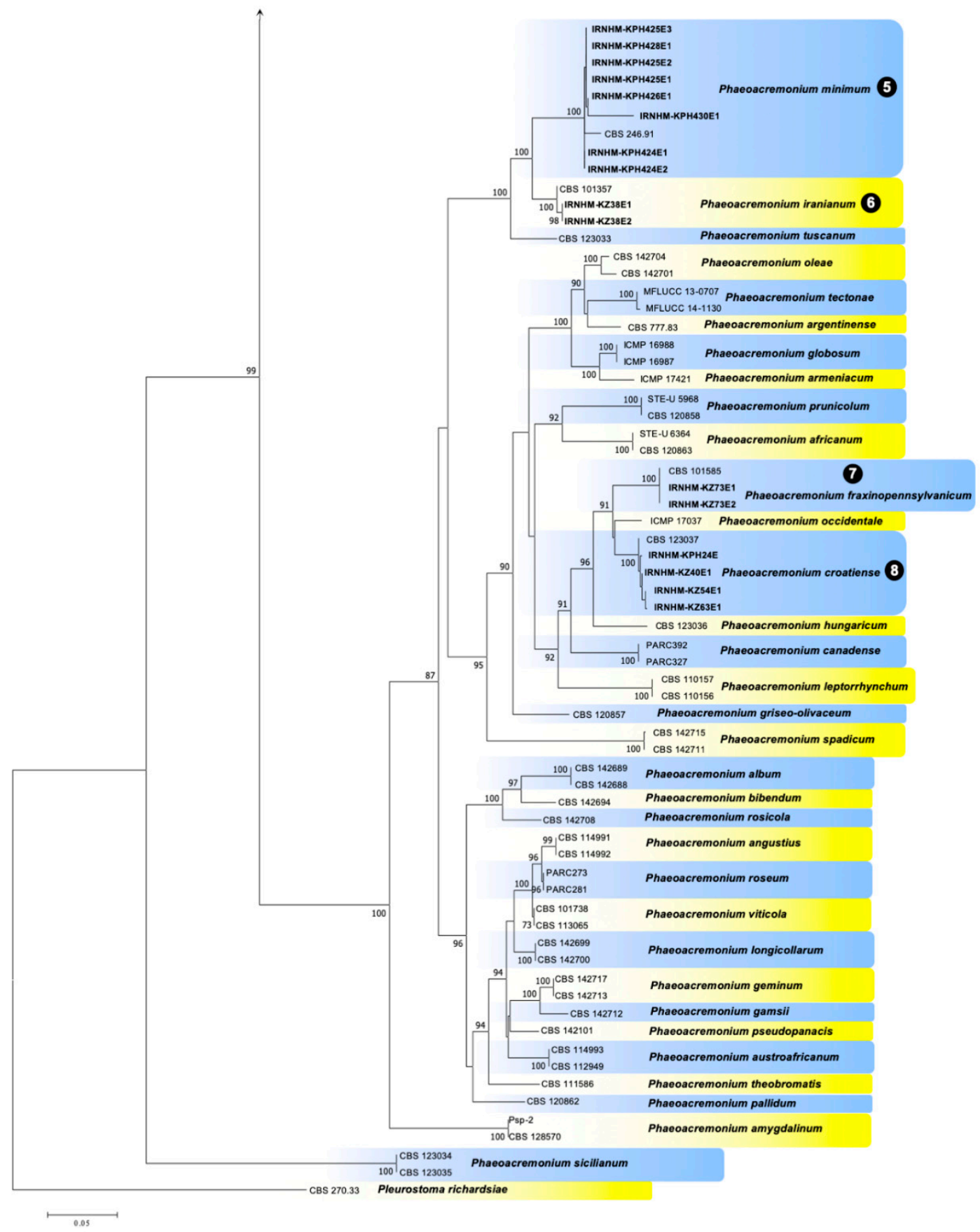

Figure 2. Maximum likelihood phylogeny of Phaeoacremonium spp. according to concatenated alignments of the actin (ACT) and beta-tubulin (BT) gene regions. Support values less than $70 \%$ bootstrap were omitted. Maximum likelihood bootstrap percentages are indicated at the nodes. Isolates obtained in this study are indicated in bold. The eight clades associated with the Phaeoacremonium spp. obtained in this study are indicated by numbers.

\subsection{Pathogenicity Test}

Mean lengths of wood discolorations caused by inoculated isolates obtained from Citrus species on the detached shoots of $C$. aurantifolia are shown in Figures 3 and 4. Our results showed a variation in the total (Figure $4 a$ ), and both the upward and downward lesion lengths (Figure $4 \mathrm{~b}$ ) from the point of inoculation and re-isolation frequencies of inoculated isolates on lime shoots. L. theobromae was the most aggressive fungal species and produced the longest necrotic lesions $(57.67 \mathrm{~mm})$ on the inoculated 
shoots followed by Do. viticola $(38.17 \mathrm{~mm})$ and P. parasiticum $(34.33 \mathrm{~mm})$ (Figure 4a). In contrast, two species of $S$. walteri $(6.33 \mathrm{~mm})$ and P. rubrigenum $(6.00 \mathrm{~mm})$ produced the smallest wood lesions on the inoculated shoots, and no significant differences were observed between these species and the control treatments $(3.67 \mathrm{~mm})$.

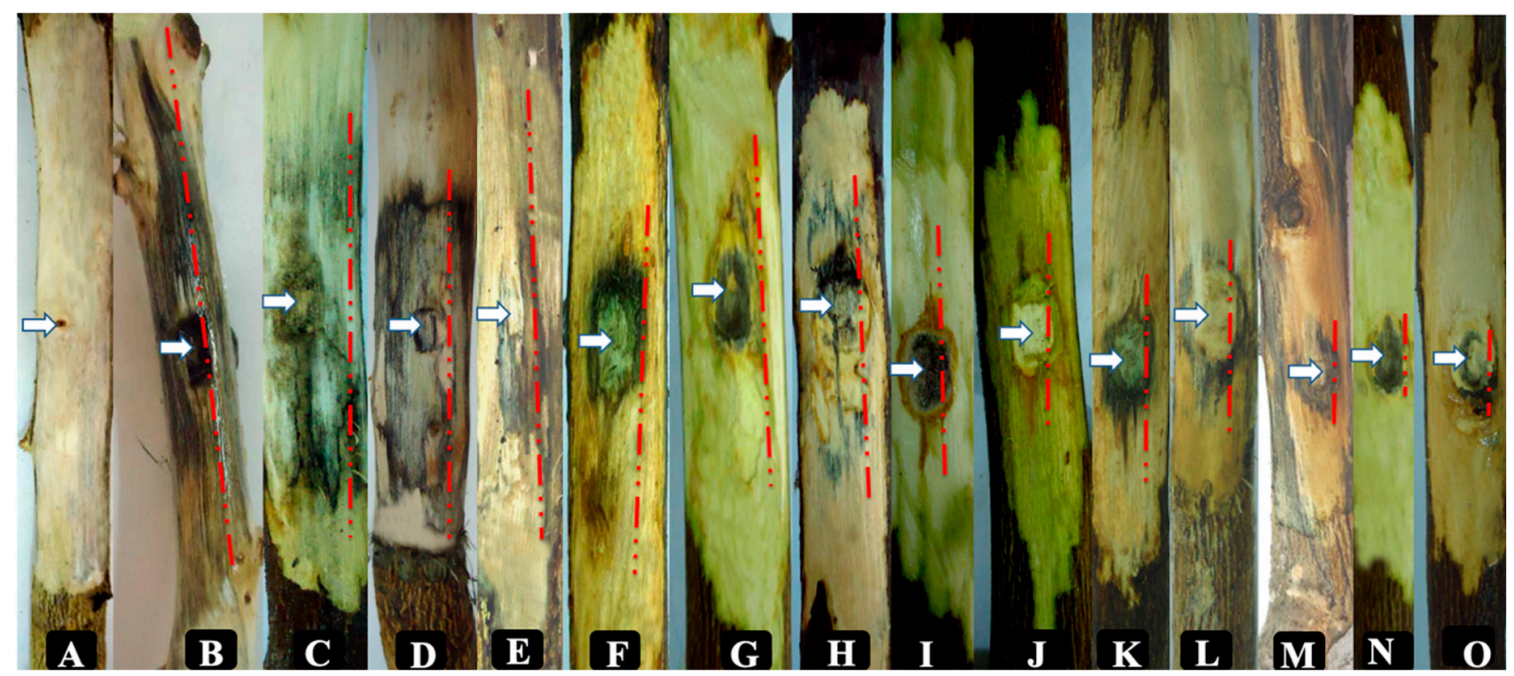

Figure 3. Pathogenicity tests of fungal species inoculated onto Citrus aurantifolia detached shoots, 40 days after inoculation: (A) control; (B,C) Lasiodiplodia theobromae; (D); Dothiorella viticola; (E) Neoscytalidium hyalinum; (F,G) Phaeoacremonium parasiticum; (H) Cadophora luteo-olivacea;

(I) Phaeoaremonium minimum; (J) Phaeoacremonium iranianum; (K) Colletotrichum gloeosporoides;

(L) Phaeoacremonium fraxinopennsylvanicum; (M) Phaeoacremonium italicum; (N) Stilbocrea walteri;

(O) Phaeoacremonium rubrigenum; (white arrows show the point of inoculation, and the red dashed lines indicate the lesion length caused by each isolate).

All inoculated fungi caused longer basipetal than acropetal lesions on the lime shoots (Figure $4 \mathrm{~b}$ ). Of the isolates inoculated, 10 species caused downward and upward wood lesions that were significantly different to those in the control $(p<0.05)$. L. theobromae also produced the longest wood lesion lengths both in upward $(22.34 \mathrm{~mm}$ ) and in downward (35.33) directions, while S. walteri (upward $=2.5$, downward $=3.83 \mathrm{~mm}$ ) and $P$. rubrigenum (upward $=2.5$, downward $=3.50 \mathrm{~mm}$ ) did not cause any significant necrotic lesion lengths both in the downward and in the upward directions compared to the control treatments (upward $=1.34$, downward $=2.33 \mathrm{~mm}$ ) on the inoculated shoots. Re-isolation percentages were between $40.0 \%$ (C. luteo-olivacea) and 100\% (L. theobromae and N. hyalinum) on the inoculated lime shoots, and no fungal isolates were recovered from control treatments. 
(A)

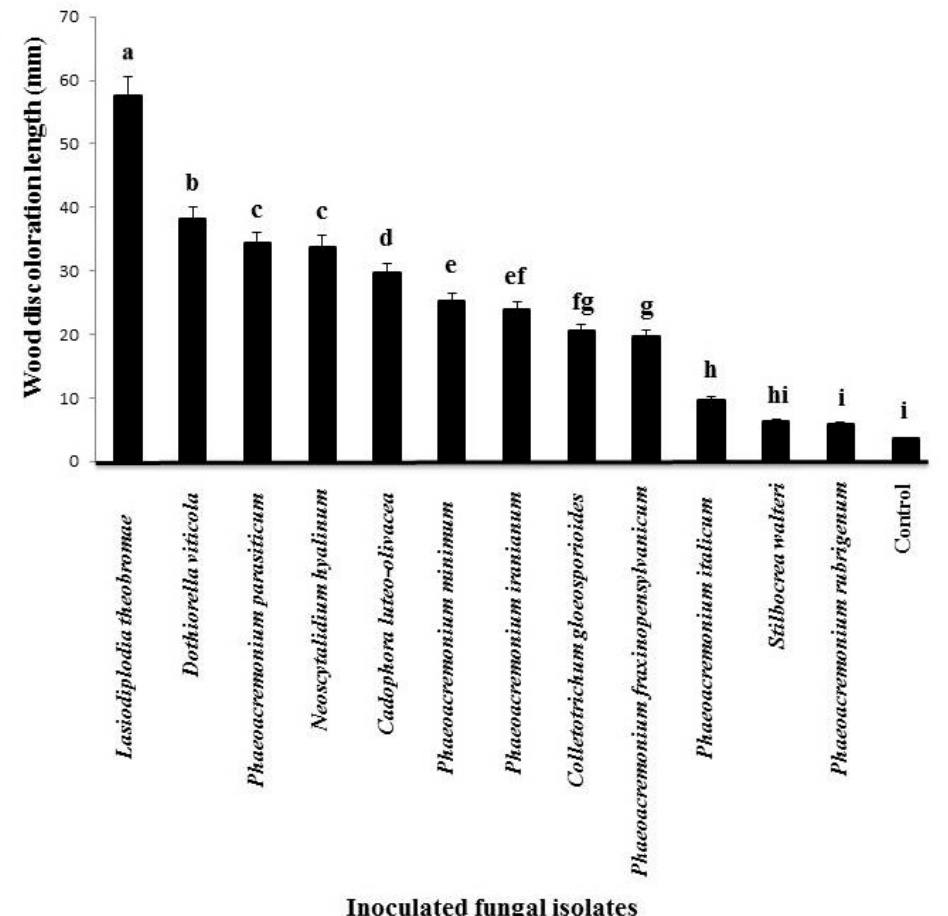

(B)

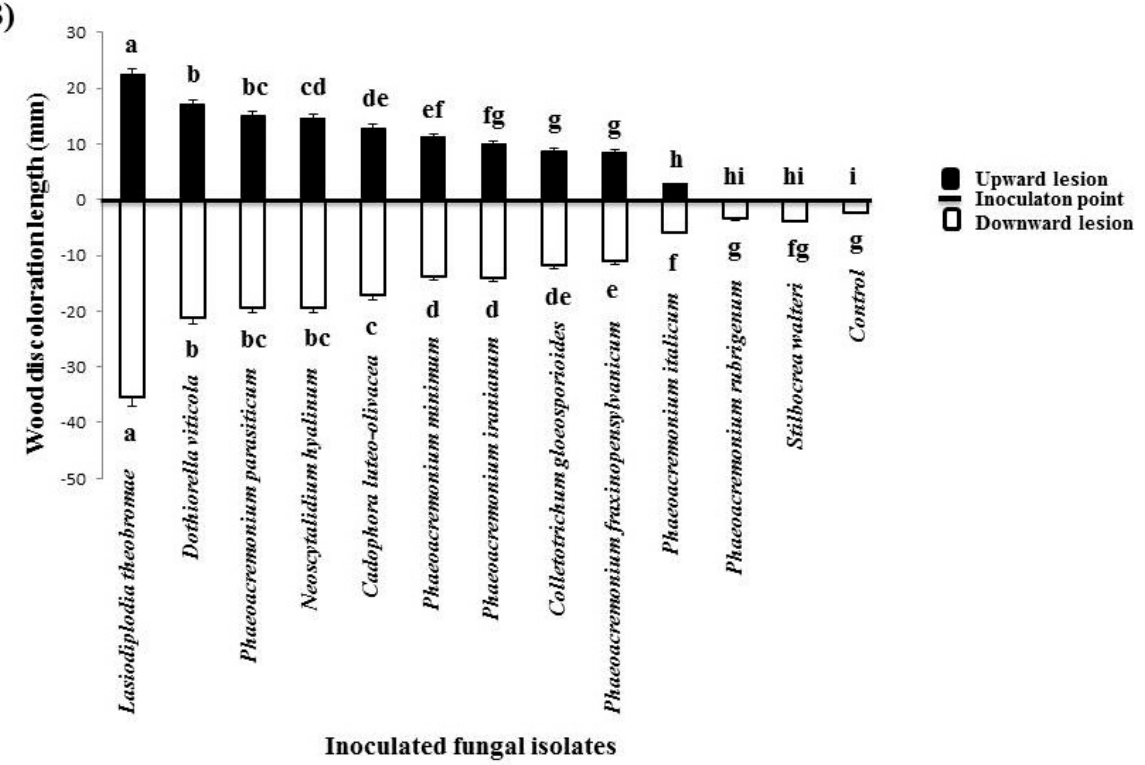

Figure 4. Total (A) and upward and downward (B) wood lesion size produced by inoculated isolates onto Citrus aurantifolia detached shoots, 40 days after inoculation. Different letters in boldface indicate significant differences at $p=0.05$. Bars represent standard error of the means.

\section{Discussion}

This study shows the high incidence and severity of fungal trunk pathogens associated with wood decay symptoms of six Citrus species (C. sinensis, C. aurantifolia, C. reticulate, C. limetta, C. aurntium, and C. limon) in Iran. During the last decade, extensive studies have been done on fungal trunk pathogens of fruit trees, including grapevine [36,37], stone [38], and pome fruit trees [28,30], pistachio [45], almond [46-48], walnut [49,50], pomegranate, and fig trees [51] in Iran. The current study shows that Citrus also represents a rich catch host for fungi associated with trunk diseases in this country. Different trunk disease fungi often co-occurred in the same tree and even in the same type of symptom, thus showing the complexity of the etiology of wood symptoms observed. The co-infection of several trunk disease fungi on woody crops could lead to an increase in disease severity compared to the 
single occurrence of a fungal species, as it has been previously demonstrated on grapevine with Botryosphaeriaceae and Ilyonectria spp. [52].

Morphological comparisons of trunk disease fungi often reveal an overlap between species in several characters $[13,16,41]$. In our study, the use of these characters to distinguish fungal species within a genus or family was inadequate, thus highlighting the convenience of DNA-based methods for such purposes. This is particularly important for species of the genus Phaeoacremonium [41]. Throughout this survey, seven Phaeoacremonium species, including P. parasiticum, P. minimum, P. rubrigenum, $P$. italicum, $P$. iranianum, $P$. croatiense, $P$. fraxinopennsylvanicum, and an unidentified species of Phaeoacremonium were recovered from Citrus spp. showing a decline in symptoms. All Phaeoacremonium species reported herein have been found associated with grapevine [41,53-55]. P. parasiticum was the dominant Phaeoacremonium species in this study, with 12 isolates collected from C. sinensis and C. aurantifolia. This fungus has previously been reported from C. reticulata in Iran [56], and from various fruit trees, such as grapevine [41], Actinidia chinensis [57], Cydonia oblonga, Ficus carica [58], Olea europaea [58,59], Malus domestica [28,58], Prunus armeniaca [24], Prunus avium [60], Punica granatum [58], and Pyrus communis [28] worlwide. In our study, P. minimum, P. rubrigenum and $P$. italicum were isolated only from C. aurantifolia. Similar to P. parasiticum, P. minimum was also reported from a wide range of fruit trees, including A. chinensis [61], A. deliciosa [62], C. oblonga [28,58], M. domestica [25,28,63], O. europaea [64], P. armeniaca [24], Prunus dulcis [57], P. pennsylvanica [65], Prunus salicina [24], P. granatum [58], P. communis [25,28], in Iran and other parts of the world. P. rubrigenum has previously been reported from C. oblonga [28], O. europaea [59], and P. communis [28]. More recently, fruit tree infections by $P$. italicum have also been reported from South Africa and this fungus has been isolated from C. oblonga, Ficus carica, M. domestica, O. europaea, P. persica, and P. granatum in this country [58]. P. croatiense was isolated from C. sinensis and C. limetta, while $P$. fraxinopennsylvanicum was isolated form $C$. aurantium. Related to fruit trees, $P$. fraxinopennsylvanicum was previously reported to affect $A$. deliciosa [62], M. domestica [28,58], P. salicina [24], and Pyrus communis [25], while $P$. croatiense was only reported from grapevine [54]. Our research confirms the broad distribution of Phaeoacremonium spp. affecting woody crops, and provides their first record on citrus trees in the world.

Three species of Botryosphaeriaceae, namely N. hyalinum, Do. viticola and L. theobromae were obtained from citrus trees in this study. Neoscytalidium hyalinum was isolated from C. aurantifolia and C. limetta, Do. viticola was recovered from C. sinensis, C. aurantifolia, and C. aurantium, and L. theobromae was associated with $C$. sinensis and C. aurantifolia. Several species of Botryosphaeriaceae are known to dieback and branch cankers in Citrus spp. worldwide $[14,20,22,23,66-70]$. Dothiorella viticola has been previously reported to cause gummosis in citrus in California [20] and Tunisia [71]. This fungus has also been reported from cultivar Parent Washington on sour orange rootstock [68], C. sinensis and C. latifolia Tan. in California [20], and C. sinensis in New Zealand [72]. Abdollahzadeh et al. reported this species from Citrus sp. in Guilan province of Iran [73]. Our study provides the first report of this fungus from C. aurantifolia and C. aurantium.

Neoscytalidium hyalinum has been reported as the most prevalent Botryosphaeriaceae species associated with citrus branch cankers in the desert regions of southern California [14]. This fungus has been recovered from C. paradise showing gummosis in California [20] and also from C. sinensis in Italy [74]. Therefore, our work is the first report of N. hyalinum from two Citrus species, C. aurantifolia and C. limetta. L. theobromae has been previously reported from some Citrus species, including C. limon in Chile [23] and Persian lime (Citrus latifolia) trees in Mexico [70]. Our study represents the first report of this species on C. sinensis and C. aurantifolia.

In the current study, 12 isolates of Cadophora luteo-olivacea were obtained from C. reticulata and C. limetta. C. luteo-olivacea has previously been reported with black vascular streaking and a decline in the symptoms characteristic of Petri disease on grapevine [44,54,75,76], bark cracks of kiwifruit [62], and from pear fruits showing dark-brown and slightly sunken spots [77]. Aside from these reports, 
little is known regarding the role of Cadophora species involved in trunk diseases of trees. This is the first time that C. luteo-olivacea has been found on Citrus spp.

Most species of the genus Biscogniauxia are reported from forest trees, mainly from Quercus spp. [78-80]. Some species of this genus have also been found associated with fruit trees such as B. pruni and B. granmoi on Prunus padus [81,82], B. marginata on M. communis [83], B. rosacearum on P. communis, C. oblonga and Prunus domestica [84], and B. capnodes on Averrhoa carambola [85]. Biscogniauxia mediterranea is known to be the causal agent of charcoal cankers on a wide range of trees worldwide, in particular Quercus spp. $[79,80,86]$. In Iran, this pathogen was already reported from C. sinensis [87], along with other woody hosts, such as Quercus castaneifolia [88], Zelkova carpinifolia [89], Q. brantii [89], and Amygdalus scoparia [90].

In the current study, eight isolates of Stilbocrea walteri were isolated from C. aurantifolia, C. aurntium, and C. limon. This species was originally reported from dead corticated branches of Quercus ilex in Portugal [91], and to our knowledge, it has not been reported from necrotic wood tissues of trees. Therefore, this study is the first report of this species in Iran and on Citrus species worldwide.

Peyronellea pinodella (Didymellaceae) is a destructive necrotrophic pathogen on some plant families, including Fabaceae, Amaranthaceae, Asteraceae, Amaryllidaceae, Appiaceae Rubiaceae, Malvaceae, Poaceae, and Polemoniaceae [92]. To date, there is no report on the occurrence of P. pinodella on Citrus species and this is the first data on the occurrence of this species on C. sinensis and C. aurantifolia.

Two species of Colletotrichum were found to be associated with trunk diseases of citrus trees in this work, C. gleoesporioides on C. sinensis and C. limetta and C. boninense on C. limetta. Several species of Colletotrichum are associated with fruit and leaf anthracnose diseases of Citrus species; however, other diseases such as twig and shoot dieback caused by Colletotrichum spp. have been documented on citrus trees [14,93]. Colletotrichum gloeosporioides has been reported from a wide range of fruit trees such as strawberry, olive, almond, mango, apple, avocado, and citrus [94]. This fungus was found to be associated with twig dieback of lemon trees in Portugal [93]. C. boninense has been associated with fruit and leaf anthracnose on citrus trees $[95,96]$. According to a recent study, some Colletotrichum species have been isolated and reported from stems of citrus trees in Iran. These included C. karstii from C. aurantifolia and C. sinensis and four species, C. gloeosporioides, C. novae-zelandiae, C. siamense, and C. fructicola from $C$. sinensis [97]. Therefore, our study represents the first report of $C$. gleoesporioides and $C$. boninense from branches of $C$. limetta.

In our work, six isolates of M. olivacea were obtained from sweet orange. This fungus has been reported from various plant species worldwide. This taxon has previously been isolated as an endophytic species from P. persica [98], from xylem and stems of Pinus sylvestris [99] and Chilean gymnosperms [100]. Carlucci et al. isolated this species from internal wood discoloration of olive trees in Italy [101]. Microsphaeropsis olivacea has also been isolated and reported from some woody plants, such as Prunus cerasus, P. avium [102], and Persian oak (Quercus brantii) [103] in Iran. To our knowledge, this is the first report of M. olivacea on citrus trees. Several isolates of Fusarium, Pestalotiopsis, Phoma, Penicillium, Aspergillus, Trichoderma, and Alternaria species were also obtained from Citrus species in this study. Therefore, more studies are needed on these taxa in order to elucidate their potential impact on citrus trunk diseases.

Pathogenicity of selected fungal species in detached shoots of lime tree were confirmed in the current study. Results revealed that $L$. theobromae was more virulent on lime shoots than other species. In contrast to our results, Bautista-Cruz et al. reported that $L$. theobromae was the least virulent species when inoculated in Persian lime branches [70]. Several factors differed from the study carried out by Bautista-Cruz et al. and might have contributed to the discrepancy between the experiments, including the type of planting material inoculated, the environmental conditions for disease development, the time for virulence assessment, and the fungal strain used in the pathogenicity test. L. theobromae has been considered the most aggressive species on Eucalyptus [104,105], grapevine [42,106], and pistachio trees [107]. Lasiodiplodia theobromae was considered an important pathogen on greengage, sour cherry, peach, apricot, cherry [38], and willow trees [29] in Iran. Our study improved the knowledge on 
the occurrence of fungal trunk pathogens on Citrus species showing a decline in symptoms. Further investigations are needed throughout the citrus orchards to determine the potential impact of these fungi on citrus decline.

\section{Materials and Methods}

\subsection{Tree Sampling and Fungal Isolation}

During 2014 and 2015, several field surveys were performed in important citrus-producing regions of Bushehr province, Tallhe and Tang Eram. This province is located in the south of Iran, within $28.7621^{\circ} \mathrm{N}$ latitude and $51.5150^{\circ} \mathrm{E}$ longitude. Symptomatic wood samples were collected from various species of citrus trees including, acid lime, sweet orange, mandarin, sour orange, sweet lemon (C. limetta), and lemon showing yellowing, defoliation, canker, dieback, and gummosis. In total, 325 wood samples were collected from branches of 106 symptomatic trees (15- to 35-year-old) in 27 orchards. A map with the point locations of the sampled orchards is shown in Figure 5. Collected samples were brought to the laboratory and inspected for internal wood lesions and fungal isolation. Small fragments $(4 \times 4 \mathrm{~mm})$ of symptomatic wood tissues were cut from the edges of wood lesions, surface-sterilized in sodium hypochlorite solution (1.5\%) for $60 \mathrm{~s}$, and rinsed three times in sterilized water. Wood chips were dried in sterilized filter paper and placed on PDA amended with 90 to $100 \mathrm{mg} / \mathrm{L}$ streptomycin sulfate (PDAS). For each branch sampled, three to five Petri dishes were obtained. All Petri dishes were incubated at $25^{\circ} \mathrm{C}$ until fungal colonies were observed. Pure cultures of the fungal isolates were obtained by hyphal-tipping or transferring single conidia to fresh PDA.
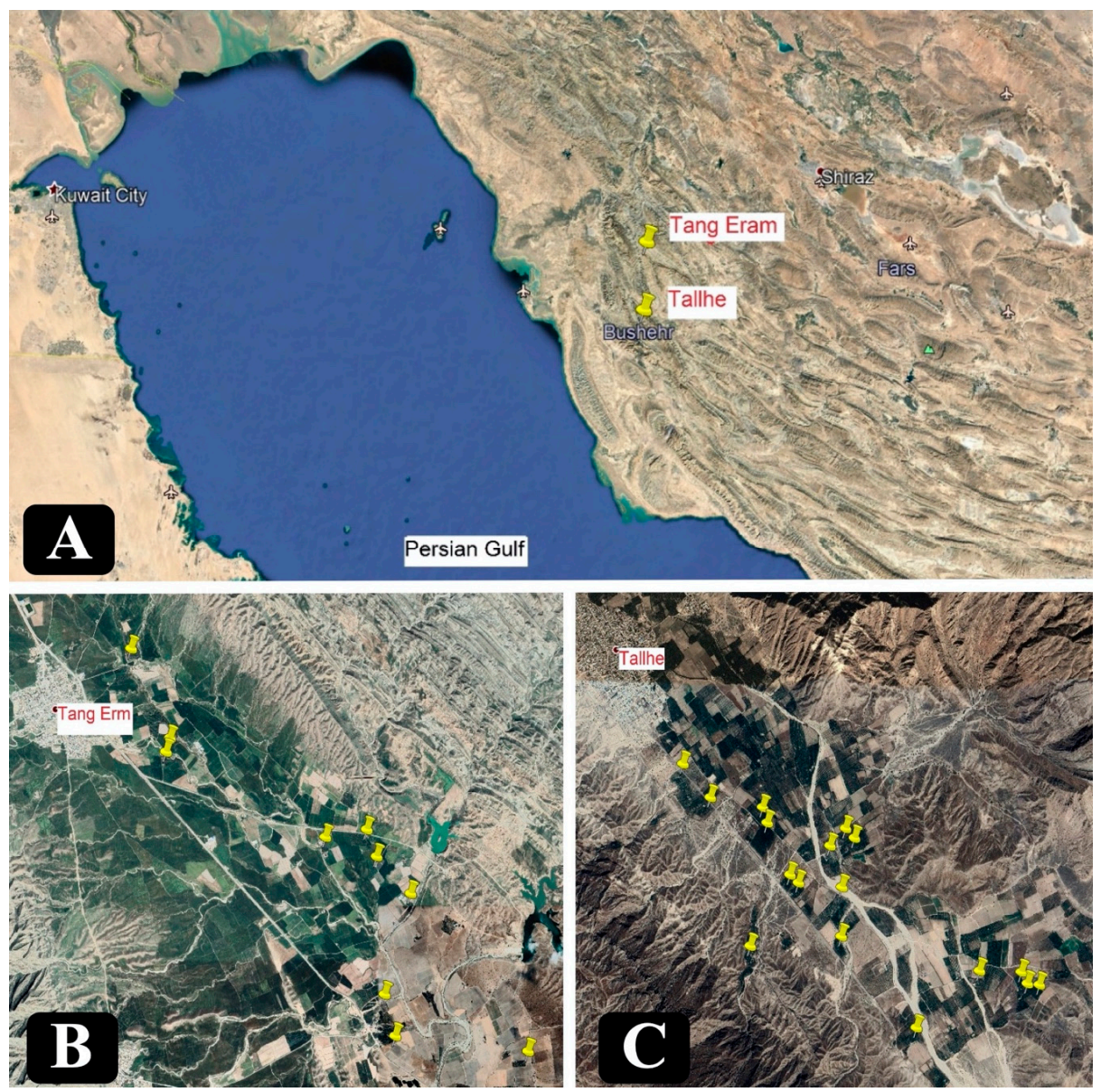

Figure 5. (A) Location of the Bushehr province. Two Citrus growing regions were surveyed, Tallhe and Tang Eram. (B) Location of surveyed orchards in the Tallhe region. (C) Location of surveyed orchards in the Tang Eram region. 


\subsection{Morphological Identification}

All fungal isolates were identified initially to the genus level based on colony morphology and main microscopic structures using published articles and descriptions. Botryosphaeriaceae isolates were identified based on colony appearance and conidial morphology $[16,108]$. To induce sporulation, three to five mycelial plugs from each isolate were placed on $2 \%$ water agar (WA; Biokar-Diagnostics) plates amended with sterilized pine needles and incubated at $25^{\circ} \mathrm{C}$ under near-ultraviolet light for 15-45 days [42]. Conidial characteristics (size, shape, color, and presence or absence of septa) were recorded for all isolates. Phaeoacremonium isolates were grouped based on colony appearance, pigment production on MEA, PDA and oatmeal agar (OA; $60 \mathrm{~g}$ oatmeal; $12.5 \mathrm{~g}$ agar; Difco, France) and the main microscopic structures (phialide shape and type, conidiophore morphology, size of hyphal warts, and conidial shape and size) $[41,57,109]$. Identification of Cadophora isolates was based on the colony and micro-morphological structures, such as conidiogenous cell size and shape, and conidia. The remaining fungal isolates were identified based on available identification keys and published papers [91,110-114].

\subsection{DNA Extraction, Amplification, and Sequencing}

Identities of representative isolates were confirmed using molecular data. Fungi selected for molecular studies were grown on PDA for 10 to 15 days at $25^{\circ} \mathrm{C}$ in the dark. DNA was extracted using an AccuPrep ${ }^{\circledR}$ Genomic DNA Extraction Kit (Bioneer, South Korea) following the instructions of the manufacturer. Four primer sets, ITS1/ITS4 [115], EF1-728F/EF1-986R [116], T1/Bt2b [117,118], and ACT-512F/ACT-783R [116] were used to amplify the ITS region ITS1-5.8S-ITS2, portions of the tef1- $\alpha$, BT and ACT genes, respectively. The identification of Botryosphaeriaceae isolates was confirmed by the sequencing of ITS and a partial sequence of tef-1a. For Phaeoacremonium isolates, a partial sequence of BT and ACT genes were amplified and sequenced. Molecular identifications of other isolates were confirmed by sequence analysis of ITS (Cadophora, Colletotrichum, Peyronellea, Stilbocrea, and Biscogniauxia isolates), BT (Colletotrichum and Peyronellea isolates), or tef1- $\alpha$ (Stilbocrea isolates). The polymerase chain reaction (PCR) was performed in a Techne TC-312 Thermal Cycler (Techne, Cambridge, UK), as described by Hashemi and Mohammadi [29]. For each isolate, 3-4 $\mu \mathrm{L}$ of PCR product was separated by electrophoresis on a $1 \%$ agarose gel (UltraPureTM Agarose, Invitrogen) containing ethidium bromide and visualized under UV illumination. The size of the products was evaluated using a 100 bp ladder (Gene Ruler, TMDNA Ladder Mix, Fermentas). PCR products were submitted to Bioneer Corporation (Daejeon, South Korea) for sequencing. MegaBLAST approach of the NCBI database (https://www.ncbi.nlm.nih.gov/) was initially used to identify fungal species.

\subsection{Phylogenetic Analysis}

Due to the broad range of Phaeoacremonium spp. obtained in this study, a phylogenetic analysis was carried out for the Phaeoacremonium spp. isolates. Sequences from citrus in Iran were aligned with sequences available in GenBank/NCBI. These were compared using MAFFT sequence alignment program v. 6 [119] with ex-type specimens from different hosts. Alignments were inspected in Sequence Alignment Editor v. 2.0a11 [120]. PAUP version $4.0 \mathrm{~b} 10$ [121] was used to perform a partition homogeneity test. The congruence between the ACT and BT datasets was tested at 1000 replicates, and the maximum likelihood (ML) was carried out on the concatenated alignment. The MEGA version 7 software [122] was used for ML analysis. Bayesian information criterion in jModelTest 2.1.10 [123] was used to estimate the best fit model. Single and concatenated datasets were tested for branch support (1000 bootstrap replicates). We included sequences published by Spies et al. as reference sequences [58]. Pleurostoma richardsiae CBS 270.33 was included as an outgroup. Phaeoacremonium sequences obtained in this study were submitted to GenBank/NCBI (Table 2) and the sequence alignments were deposited in TreeBASE under study number 26006 (http://treebase.org). 
Table 2. Host, origin, and GenBank accession numbers of Phaeoacremonium isolates obtained from Citrus spp. in Iran (used in phylogenetic studies).

\begin{tabular}{|c|c|c|c|c|}
\hline \multicolumn{2}{|c|}{ Fungal Isolates } & \multirow{2}{*}{ Citrus spp. } & \multicolumn{2}{|c|}{ GenBank Accession Number } \\
\hline Phaeoacremonium Species & Code & & b-Tubulin & Actin \\
\hline \multirow[t]{12}{*}{ P. parasiticum } & IRNHM-KPH35* & C. aurantifolia & KU737504 & MT127573 \\
\hline & IRNHM-KPH35E1 & C. sinensis & MT122909 & MT127574 \\
\hline & IRNHM-KPH35E2 & C. aurantifolia & MT122910 & MT127575 \\
\hline & IRNHM-KPH35E3 & C. aurantifolia & MT122911 & MT127576 \\
\hline & IRNHM-KPH35E4 & C. aurantifolia & MT122912 & MT127577 \\
\hline & IRNHM-KPH35E5 & C. aurantifolia & MT122913 & MT127578 \\
\hline & RNHM-KPH35E6 & C. aurantifolia & MT122914 & MT127579 \\
\hline & IRNHM-KPH35E7 & C. aurantifolia & MT122915 & MT127580 \\
\hline & IRNHM-KPH35E8 & C. aurantifolia & MT122916 & MT127581 \\
\hline & IRNHM-KPH35E9 & C. aurantifolia & MT122917 & MT127582 \\
\hline & IRNHM-KPH35E10 & C. aurantifolia & MT122918 & MT127583 \\
\hline & IRNHM-KPH35E11 & C. aurantifolia & MT122919 & MT127584 \\
\hline \multirow[t]{2}{*}{ Phaeoacremonium sp. } & IRNHM-KPH61 & C. aurantifolia & KU737517 & MT127585 \\
\hline & IRNHM-KPH61E4 & C. aurantifolia & MT122920 & MT127586 \\
\hline \multirow[t]{5}{*}{ P. italicum } & IRNHM-KPH61E1 & C. aurantifolia & MT122921 & MT127587 \\
\hline & IRNHM-KPH61E2* & C. aurantifolia & MT122922 & MT127588 \\
\hline & IRNHM-KPH61E3 & C. aurantifolia & MT122923 & MT127589 \\
\hline & IRNHM-KPH63E1 & C. aurantifolia & MT122924 & MT127590 \\
\hline & IRNHM-KPH63E2 & C. aurantifolia & MT122925 & MT127591 \\
\hline \multirow[t]{6}{*}{ P. rubrigenum } & IRNHM-KPH91E1 & C. aurantifolia & MT122926 & MT127592 \\
\hline & IRNHM-KPH91E2 & C. aurantifolia & MT122927 & MT127593 \\
\hline & IRNHM-KPH91E3 & C. aurantifolia & MT122928 & MT127594 \\
\hline & IRNHM-KPH91E4* & C. aurantifolia & MT122929 & MT127595 \\
\hline & IRNHM-KPH424E1 & C. aurantifolia & MT122930 & MT127596 \\
\hline & IRNHM-KPH424E2 & C. aurantifolia & MT122931 & MT127597 \\
\hline \multirow[t]{6}{*}{ P. minimum } & IRNHM-KPH425E1* & C. aurantifolia & MT122932 & MT127598 \\
\hline & IRNHM-KPH425E2 & C. aurantifolia & MT122933 & MT127599 \\
\hline & IRNHM-KPH425E3 & C. aurantifolia & MT122934 & MT127600 \\
\hline & IRNHM-KPH426E1 & C. aurantifolia & MT122935 & MT127601 \\
\hline & IRNHM-KPH428E1 & C. aurantifolia & MT122936 & MT127602 \\
\hline & IRNHM-KPH430E1 & C. aurantifolia & MT122937 & MT127603 \\
\hline \multirow[t]{2}{*}{ P. iranianum } & IRNHM-KZ38E1 & C. reticulata & MT122938 & MT127604 \\
\hline & IRNHM-KZ38E2* & C. reticulata & MT122939 & MT127605 \\
\hline \multirow[t]{4}{*}{ P. croatiense } & IRNHM-KPH24E & C. sinensis & MT122940 & MT127606 \\
\hline & IRNHM-KZ40E1 & C. limetta & MT122941 & MT127607 \\
\hline & IRNHM-KZ54E1 & C. limetta & MT122942 & MT127608 \\
\hline & IRNHM-KZ63E1 & C. sinensis & MT122943 & MT127609 \\
\hline \multirow[t]{2}{*}{ P. fraxinopennsylvanicum } & IRNHM-KZ73E1* & C. limon & MT122944 & MT127610 \\
\hline & IRNHM-KZ73E2 & C. aurantium & MT122945 & MT127611 \\
\hline
\end{tabular}

Isolates used for pathogenicity tests on detached shoots of C. aurantifolia.

\subsection{Pathogenicity Tests}

Pathogenicity tests were carried out with 12 species on detached shoots of $C$. aurantifolia under controlled conditions. These include Do. viticola, P. italicum, P. minimum, P. rubrigenum, and P. parasiticum isolated from C. aurantifolia, L. theobromae, and Col. gloeosporioides obtained from C. sinensis, C. luteo-olivacea, and N. hyalinum recovered from C. limetta, P. fraxinopensylvanicum from C. limon, P. iranianum from C. reticulata and S. walteri isolated from C. aurantium. The shoots $(38-40 \mathrm{~cm}$ in length and $2-2.5 \mathrm{~cm}$ in diameter) were surface-disinfected with alcohol (96\%) and then were wounded at the uppermost internode with a 4-mm cork borer. To assess pathogenicity, wounds were inoculated with a 4-mm colonized PDA agar from 14-days-old cultures. All inoculated sites first were covered by moist cotton and then were wrapped with a strip of Parafilm (Pechiney Plastic Packaging, Menasha, USA). Six shoots per fungal isolate were used, and an equal number of shoots were also inoculated 
with 4-mm non-colonized PDA agar plugs for negative controls. Inoculated shoots were arranged at random, including the six inoculated shoots per isolate. Inoculated shoots were placed in moist chambers and incubated at $25^{\circ} \mathrm{C}$. The total, upward, and downward lesion length data were evaluated individually, 40 days after inoculation. Recorded data were checked for normality of distribution by means of the Shapiro-Wilk and Kolmogorov-Smirnov tests. The data were subjected to analysis of variance (one-way ANOVA) using SAS v 9.1 (SAS Institute, Cary, NC, USA) (Dataset S1; Dataset S2). The least significant difference (LSD) test was used for comparison of treatment means at $p<0.05$. Fungal re-isolations were made from the edges of the lesions on the test and control shoots and placed on PDA. The identity of the re-isolated fungi was confirmed based on morphological characteristics and molecular analysis in order to complete Koch's postulates. The pathogenicity of other species was not tested in this work because they were identified after the pathogenicity trials had begun on the detached shoots of C. aurantifolia.

Supplementary Materials: The following are available online at http://www.mdpi.com/2223-7747/9/6/754/s1, Dataset S1: SAS code, Dataset S2: Lesion length data.

Author Contributions: Conceived the idea of the research, designed the scientific experiments and methodology, H.M.; field surveys, sample preparation, laboratory works, sequencing of fungal isolates, pathogenicity tests, N.E.; software, H.M. and D.G.; writing—original draft preparation, H.M.; writing-review and editing, H.M. and D.G.; supervision, H.M.; phylogenetic analysis, D.G. All authors have read and agreed to the published version of the manuscript.

Funding: This research received no external funding.

Conflicts of Interest: The authors declare no conflict of interest.

\section{References}

1. FAO. Citrus Fruit Fresh and Processed. Statistical Bulletin. 2016. Available online: http://fao.org/3/a-i8092e. pdf (accessed on 15 May 2020).

2. Gramaje, D.; Úrbez-Torres, J.R.; Sosnowski, M.R. Managing grapevine trunk diseases with respect to etiology and epidemiology: Current strategies and future prospects. Plant Dis. 2018, 102, 12-39. [CrossRef] [PubMed]

3. Gramaje, D.; Baumgartner, K.; Halleen, F.; Mostert, L.; Sosnowski, M.R.; Úrbez-Torres, J.R.; Armengol, J. Fungal trunk diseases: A problem beyond grapevines? Plant Pathol. 2016, 65, 355-356. [CrossRef]

4. Carter, M.V. The Status of Eutypa Lata as a Pathogen. Monograph, Phytopathological Paper No 32; Commonwealth Agricultural Bureau, International Mycological Institute: Surrey, UK, 1991.

5. Munkvold, G.P.; Marois, J.J. Eutypa dieback of sweet cherry and occurrence of Eutypa lata perithecia in the central valley of California. Plant Dis. 1994, 78, 200-207. [CrossRef]

6. Sinclair, W.A.; Lyon, H.H. Diseases of Trees and Shrubs, 2nd ed.; Cornell University Press: Ithaca, NY, USA, 2005; p. 659.

7. Jurc, D.; Ogris, N.; Slippers, B.; Stenlid, J. First report of Eutypella canker of Acer pseudoplatanus in Europe. Plant Pathol. 2006, 55, 577. [CrossRef]

8. Úrbez-Torres, J.R.; Adams, P.; Kama, J.; Gubler, W.D. Identification, incidence and pathogenicity of fungal species associated with grapevine dieback in Texas. Am. J. Enol. Vitic. 2009, 60, 497-507.

9. Reinking, O.A. Philippine economic plant diseases. Philipp. J. Sci. 1918, 13, 165-274.

10. Rappaz, F. Taxonomie et nomenclature des Diatrypacees a asques octosporees. Mycol. Helv. 1987, 2, $285-648$.

11. Resplandy, R.; Chevaugeon, J.; Delassus, M.; Luc, M. Premiere liste annotee de champignons parasites de plantes cultivees en Cote d'Ivoire. Ann. Epiphyt. 1954, 1, 1-61.

12. Hanlin, R.T. Index to genera and species of ascomycetes described by A. P. Viegas. Mycotaxon 1992, 43, 207-230.

13. Trouillas, F.P.; Pitt, W.M.; Sosnowski, M.R.; Huang, R.; Peduto, F.; Loschiavo, A.; Savocchia, S.; Scott, E.S.; Gubler, W.D. Taxonomy and DNA phylogeny of Diatrypaceae associated with Vitis vinifera and other woody plants in Australia. Fungal Divers. 2011, 49, 203-223. [CrossRef]

14. Mayorquin, J.S.; Wang, D.H.; Twizeyimana, M.; Eskalen, A. Identification, distribution, and pathogenicity of Diatrypaceae and Botryosphaeriaceae associated with citrus branch canker in the southern California desert. Plant Dis. 2016, 2016. 100, 2402-2413. [CrossRef] 
15. Trouillas, F.P.; Urbez-Torres, J.R.; Gubler, W.D. Diversity of Diatrypaceous fungi associated with grapevine canker diseases in California. Mycologia 2010, 102, 319-336. [CrossRef] [PubMed]

16. Phillips, A.J.L.; Alves, A.; Abdollahzadeh, J.; Slippers, B.; Wingfield, M.J.; Groenewald, J.Z.; Crous, P.W. The Botryosphaeriaceae: Genera and species known from culture. Stud. Mycol. 2013, 76, 51-167. [CrossRef] [PubMed]

17. Slippers, B.; Boissin, E.; Phillips, A.J.; Groenewald, J.Z.; Lombard, L.; Wingfield, M.J.; Postma, A.; Burgess, T.; Crous, P.W. Phylogenetic lineages in the Botryosphaeriales: A systematic and evolutionary framework. Stud. Mycol. 2013, 76, 31-49. [CrossRef] [PubMed]

18. Dissanayake, A.J.; Phillips, A.J.L.; Li, X.H.; Hyde, K.D. Botryosphaeriaceae: Current status of genera and species. Mycosphere 2016, 7, 1001-1073. [CrossRef]

19. Abdollahzadeh, J.; Javadi, A.; Mohammadi Goltapeh, E.; Zare, R.; Phillips, A.J.L. Phylogeny and morphology of four new species of Lasiodiplodia from Iran. Persoonia 2010, 25, 1-10. [CrossRef]

20. Adesemoye, A.O.; Mayorquin, J.S.; Wang, D.H.; Twizeyimana, M.; Lynch, S.C.; Eskalen, A. Identification of species of Botryosphaeriaceae causing bot gummosis in citrus in California. Plant Dis. 2014, 98, 55-61. [CrossRef]

21. Linaldeddu, B.T.; Dedda, A.; Scanu, B.; Franceschini, A.; Serra, S.; Berraf-Tebbal, A.; Zouaoui Boutiti, M.; Ben Jamâa, M.L.; Phillips, A.J.L. Diversity of Botryosphaeriaceae species associated with grapevine and other woody hosts in Italy, Algeria and Tunisia, with descriptions of Lasiodiplodia exigua and Lasiodiplodia mediterranea sp. nov. Fungal Divers. 2015, 71, 201-214. [CrossRef]

22. Coutinho, I.B.L.; Freire, F.C.O.; Lima, C.S.; Lima, J.S.; Gonçalves, F.J.T.; Machado, A.R.; Silva, A.M.S.; Cardoso, J.E. Diversity of genus Lasiodiplodia associated with perennial tropical fruit plants in northeastern Brazil. Plant Pathol. 2017, 66, 90-104. [CrossRef]

23. Guajardo, J.; Riquelme, N.; Tapia, L.; Larach, A.; Torres, C.; Camps, R.; Besoain, X. First report of Lasiodiplodia theobromae causing bot gummosis in Citrus limon in Chile. Plant Dis. 2018, 102, 818. [CrossRef]

24. Damm, U.; Mostert, L.; Crous, P.W.; Fourie, P.H. Novel Phaeoacremonium species associated with necrotic wood of Prunus trees. Persoonia 2008, 20, 87-102. [CrossRef]

25. Cloete, M.; Fourie, P.H.; Damm, U.; Crous, P.W.; Mostert, L. Fungi associated with die-back symptoms of apple and pear trees, a possible inoculum source of grapevine trunk disease pathogens. Phytopathol. Mediterr. 2011, 50, S176-S190.

26. Gramaje, D.; Agustí-Brisach, C.; Pérez-Sierra, A.; Moralejo, E.; Olmo, D.; Mostert, L.; Damm, U.; Armengol, J. Fungal trunk pathogens associated with wood decay of almond trees on Mallorca (Spain). Persoonia 2012, 28, 1-13. [CrossRef] [PubMed]

27. Olmo, D.; Gramaje, D.; Agustí-Brisach, C.; Leon, M.; Armengol, J. First report of Phaeoacremonium venezuelense associated with decay of apricot trees in Spain. Plant Dis. 2014, 98, 1001. [CrossRef] [PubMed]

28. Sami, S.; Mohammadi, H.; Heydarnejad, J. Phaeoacremonium species associated with necrotic wood of pome fruit trees in Iran. J. Plant Pathol. 2014, 96, 487-495.

29. Hashemi, H.; Mohammadi, H. Identification and characterization of fungi associated with internal wood lesions and decline disease of willow and poplar trees in Iran. For. Pathol. 2016, 46, 341-352. [CrossRef]

30. Mohammadi, H.; Sharifi, S. Association of Botryosphaeriaceae and Phaeoacremonium species with insect-damaged quince shoots. J. Plant Pathol. 2016, 98, 35-42.

31. Kazemzadeh Chakusary, M.; Mohammadi, H.; Khodaparast, A. Decline-associated Phaeoacremonium spp. occurring on forest trees in the north of Iran. For. Pathol. 2017, 47, e12368. [CrossRef]

32. Marin-Felix, Y.; Hernández-Restrepo, M.; Wingfield, M.J.; Akulov, A.; Carnegie, A.J.; Cheewangkoon, R.; Gramaje, D.; Groenewald, J.Z.; Guarnaccia, V.; Halleen, F.; et al. Genera of phytopathogenic fungi: GOPHY 2. Stud. Mycol. 2018, 92, 47-133. [CrossRef]

33. Gramaje, D.; Mostert, L.; Groenewald, J.Z.; Crous, P.W. Phaeoacremonium: From esca disease to phaeohyphomycosis. Fungal Biol. 2015, 119, 759-783. [CrossRef]

34. Baloyi, M.A.; Mostert, L.; Halleen, F. Pathogenicity of ten Phaeoacremonium species associated with esca and Petri disease of grapevine. Phytopathol. Mediterr. 2018, 57, 538-546.

35. Mugnai, L.; Graniti, A.; Surico, G. Esca (black measles) and Brown wood-streaking: Two old and elusive diseases of grapevines. Plant Dis. 1999, 83, 404-416. [CrossRef] [PubMed]

36. Mohammadi, H.; Banihashemi, Z.; Gramaje, D.; Armengol, J. Fungal pathogens associated with grapevine trunk diseases in Iran. J. Agric. Sci. Technol. 2013, 15, 137-150. 
37. Mohammadi, H.; Banihashemi, Z.; Gramaje, D.; Armengol, J. Characterization of Diplodia seriata and Neofusicoccum parvum associated with grapevine decline in Iran. J. Agric. Sci. Technol. 2013, 15, 603-616.

38. Soltaninejad, N.; Mohammadi, H.; Massumi, H. Isolation, identification and pathogenicity of Botryosphaeriaceae and Phaeoacremonium species associated with decline of prunus species in Iran. J. Plant Pathol. 2017, 99, 571-581. [CrossRef]

39. Hashemi, H.; Mohammadi, H.; Abdollahzadeh, J. Symptoms and fungi associated with elm trees decline in Iran. Eur. J. For. Res. 2017, 136, 857-879. [CrossRef]

40. Panahandeh, S.; Mohammadi, H.; Gramaje, D. Trunk disease fungi associated with Syzygium cumini in Iran. Plant Dis. 2019, 103, 711-720. [CrossRef]

41. Mostert, L.; Groenewald, J.Z.; Summerbell, R.C.; Gams, W.; Crous, P.W. Taxonomy and pathology of Togninia (Diaporthales) and its Phaeoacremonium anamorphs. Stud. Mycol. 2006, 54,1-115. [CrossRef]

42. Van Niekerk, J.M.; Crous, P.W.; Groenewald, J.Z.; Fourie, P.H.; Halleen, F. DNA phylogeny, morphology and pathogenicity of Botryosphaeria species on grapevines. Mycologia 2004, 96, 781-798. [CrossRef]

43. Harrington, T.C.; McNew, D.L. Phylogenetic analysis places the Phialophora-like anamorph genus Cadophora in the Helotiales. Mycotaxon 2003, 87, e151.

44. Gramaje, D.; Mostert, L.; Armengol, J. Characterization of Cadophora luteo-olivacea and C. melinii isolates obtained from grapevines and environmental samples from grapevine nurseries in Spain. Phytopathol. Mediterr. 2011, 50, S112-S126.

45. Mohammadi, H.; Sarcheshmehpour, M.; Mafi, E. Fungal trunk pathogens associated with wood decay of pistachio trees in Iran. Span. J. Agric. Res. 2015, 2, 6. [CrossRef]

46. Mousavi, M.; Mohammadi, H.; Soltaninejad, N. First report of Phaeoacremonium aleophilum (Ascomycota, Calosphaeriales) on almond and cherry trees in Kerman province. In Proceedings of the 21th Iranian Plant Protection Congress, Urmia, Iran, 23-26 August 2014; p. 28.

47. Sohrabi, M.; Mohammadi, H. Phaeoacremonium spp. and Pleurostoma richardsiae associated with trunk diseases of almond trees in Iran. In Proceedings of the 3rd Iranian Mycological Congress, University of Kurdistan, Sanandaj, Iran, 26-28 August 2017; p. 51.

48. Sohrabi, M.; Mohammadi, H. First report of Lasiodiplodia theobromae from almond trees in Iran. In Proceedings of the International Conference on Agricultural Science Medical Plants Traditional Medicine, Payam Noor University, Mashhad, Iran, 14-15 February 2018; pp. 1-11.

49. Sohrabi, M.; Mohammadi, H. Report on two species of Phaeoacremonium from walnut trees (Juglans regia L.) in Iran. In Proceedings of the 3rd Iranian Mycological Congress, University of Kurdistan, Sanandaj, Iran, 26-28 August 2017; p. 50.

50. Sohrabi, M.; Mohammadi, H.; Leon, M.; Armengol, J.; Banihashemi, Z. Detection of Phaeoacremonium spp. associated with decline of walnut trees (Juglanconis regia) in Kerman and Fars provinces. In Proceedings of the 4th Iranian Mycological Congress, Sari Agricultural Sciences and Nutural Resources University, Sari, Iran, 26-28 August 2019; p. 61.

51. Kadkhodahemmatabadi, S. Study of Disease Symptoms and Fungi Associated with Decline of Pomegranate and Fig Trees in Fars and Kerman Provinces. Master's Thesis, Shahid Bahonar University of Kerman, Kerman, Iran, 2018.

52. Whitelaw-Weckert, M.A.; Rahman, L.; Appleby, L.M.; Hall, A.; Clark, A.C.; Waite, H.; Hardie, W.J. Co-infection by Botryosphaeriaceae and Ilyonectria spp. fungi during propagation causes decline of young grafted grapevines. Plant Pathol. 2013, 62, 1226-1237. [CrossRef]

53. Essakhi, S.; Mugnai, L.; Crous, P.W.; Groenewald, J.Z.; Surico, G. Molecular and phenotypic characterization of novel Phaeoacremonium species associated with Petri disease and esca of grapevine. Persoonia 2008, 21, 119-134. [CrossRef] [PubMed]

54. Raimondo, M.L.; Lops, F.; Carlucci, A. Phaeoacremonium italicum sp nov., a new species associated with esca of grapevine in southern Italy. Mycologia 2014, 106, 1119-1126. [CrossRef]

55. Úrbez-Torres, J.R.; Haag, P.; Bowen, P.; O'Gorman, D.T. Grapevine trunk diseases in British Columbia: Incidence and characterization of the fungal pathogens associated with esca and Petri diseases of grapevine. Plant Dis. 2014, 98, 469-482. [CrossRef] [PubMed]

56. Sadeghi, F.; Samsampour, D.; Seyahooei, M.A.; Bagheri, A.; Soltani, J. Diversity and spatiotemporal distribution of fungal endophytes associated with Citrus reticulata cv. Siyahoo. Curr. Microbiol. 2019, 76, 279-289. [CrossRef] [PubMed] 
57. Di Marco, S.; Calzarano, F.; Osti, F.; Mazzullo, A. Pathogenicity of fungi associated with a decay of kiwifruit. Australas. Plant Pathol. 2004, 33, 337-342. [CrossRef]

58. Spies, C.F.J.; Moyo, P.; Halleen, F.; Mostert, L. Phaeoacremonium species diversity on woody hosts in the Western Cape Province of South Africa. Persoonia 2018, 40, 26-62. [CrossRef]

59. Nigro, F.; Boscia, D.; Antelmi, I.; Ippolito, A. Fungal species associated with a severe decline of olive in southern Italy. J. Plant Pathol. 2013, 95, 668.

60. Rumbos, I. Phialophora parasitica, causal agent of cherry dieback. J. Phytopathol. 1986, 117, 283-287. [CrossRef]

61. Crous, P.W.; Gams, W. Phaeomoniella chlamydospora gen. et comb. nov., a causal organism of Petri grapevine decline and esca. Phytopathol. Mediterr. 2000, 39, 112-188.

62. Prodi, A.; Sandalo, S.; Tonti, S.; Nipoti, P.; Pisi, A. Phialophora-like fungi associated with kiwifruit elephantiasis. J. Plant Pathol. 2008, 90, 487-494.

63. Arzanlou, M.; Narmani, A.; Khodaei, S.; Moshari, S. Pome and stone fruit trees as possible reservoir hosts for Phaeoacremonium spp., the causal agents of grapevine esca disease, in Iran. Arch. Phytopathol. Plant Protect. 2014, 47, 717-727. [CrossRef]

64. Úrbez-Torres, J.R.; Peduto, F.; Vossen, P.M.; Krueger, W.H.; Gubler, W.D. Olive twig and branch dieback: Etiology, incidence, and distribution in California. Plant Dis. 2013, 97, 231-244. [CrossRef]

65. Hausner, G.; Eyjólfsdóttir, G.; Reid, J. Two additional species of the genus Togninia. Can. J. Bot. 1992, 70, 724-734. [CrossRef]

66. Calavan, E.C.; Wallace, J.M. Hendersonula toruloidea Nattrass on citrus in California. Phytopathology 1954, 44, 635-639.

67. Punithalingham, E. Plant diseases attributed to Botryodiplodia theobromae Pat. Bibl. Mycol. 1980, 71, 21-26.

68. Whiteside, J.O. Dothiorella Gummosis. In Compendium of Citrus Diseases, 1st ed.; Whiteside, J.O., Garnsey, S.M., Timmer, L.W., Eds.; American Phytopathological Society: St. Paul, MN, USA, 1980; p. 14.

69. Adesemoye, A.O.; Eskalen, A. First report of Spencermartinsia viticola, Neofusicoccum australe, and N. parvum causing branch canker of citrus in California. Plant Dis. 2011, 95, 770. [CrossRef]

70. Bautista-Cruz, M.A.; Almaguer-Vargas, G.; Leyva-Mir, S.G.; Colinas-León, M.T.; Correia, C.K.; Camacho-Tapia, M.; Robles-Yerena, L.; Michereff, S.J.; Tovar-Pedraza, J.M. Phylogeny, distribution, and pathogenicity of Lasiodiplodia species associated withcankers and dieback symptoms of Persian lime in Mexico. Plant Dis. 2018, 103. [CrossRef]

71. Hamrouni, N.; Nouri, M.T.; Trouillas, F.P.; Said, A.; Sadfi-Zouaoui, N.; Hajlaoui, M.R. Dothiorella gummosis caused by Dothiorella viticola, first record from citrus in Tunisia. New Dis. Rep. 2018, 38, 10. [CrossRef]

72. Abdollahzadeh, J.; Javadi, A.; Zare, R.; Phillips, A.J.L. A phylogenetic study of Dothiorella and Spencermatinsia species associated with woody plants in Iran, New Zealand, Portugal and Spain. Persoonia 2014, 32, 1-12.

73. Abdollahzadeh, J.; Hosseini, F.; Javadi, A. New records from Botryosphaeriaceae (Ascomycota) for mycobiota of Iran. Mycol. Iran. 2014, 1, 43-51.

74. Polizzi, G.; Aiello, D.; Vitale, A.; Giuffrida, F.; Groenewald, J.Z.; Crous, P.W. First report of shoot blight, canker, and gummosis caused by Neoscytalidium dimidiatum on citrus in Italy. Plant Dis. 2009, 93, 1215. [CrossRef]

75. Overton, E.B.; Steward, E.L.; Wenner, N.G. Molecular phylogenetics of grapevine decline fungi from Pennsylvania and New York. Phytopathol. Mediterr. 2005, 44, 90-91.

76. Travadon, R.; Lawrence, D.P.; Rooney-Latham, S.; Gubler, W.D.; Wilcox, W.F.; Rolshausen, P.E.; Baumgartner, K. Cadophora species associated with wood-decay of grapevine in North America. Fungal Biol. 2015, 119, 53-66. [CrossRef] [PubMed]

77. Spadaro, D.; Pellegrino, C.; Garibaldi, A.; Gullino, M.L. Development of SCAR primers for the detection of Cadophora luteo-olivacea on kiwifruit and pome fruit and of Cadophora malorum on pome fruit. Phytopathol. Mediterr. 2011, 50, 430-441.

78. De Sousa Santos, M.N. Contribuicão para conhecimento das relacoes Quercus suber-Biscogniauxia mediterranea (syn. Hypoxylon mediterraneum). Silva Lusit. 2003, 11, 21-29.

79. Vannini, A.; Scarascia Mugnozza, G. Water stress: A predisposing factor in the pathogenesis of Hypoxylon mediterraneum on Quercus cerris. Eur. J. For. Pathol. 1991, 21, 193-201. [CrossRef]

80. Vannini, A.; Biocca, M.; Paparatti, B. Contributo alla conoscenza del ciclo biologico di Hypoxylon mediterraneum (De Not.) Mill. su Quercus cerris. Inf. Fitopatol. 1996, 56, 53-55.

81. Læssøe, T.; Scheuer, C.; Granmo, A. Biscogniauxia granmoi (Xylariaceae) in Europe. Österr. Z. Pilzkd. 1999, 8 , 139-147. 
82. Vasilyeva, L.N. The taxonomic position of Camarops polysperma (Mont.) J. H. Miller and Biscogniauxia Kuntze in the Far East. Mikol. Fitopatol. 1988, 22, 388-396.

83. Pouzar, Z. Notes on taxonomy and nomenclature of Nummularia (Pyrenomycetes). Ceska Mykol. 1979, 33, 207-219.

84. Raimondo, M.L.; Lops, F.; Carlucci, A. Charcoal canker of pear, plum, and quince trees caused by Biscogniauxia rosacearum sp. nov. in Southern Italy. Plant Dis. 2016, 100, 1813-1822. [CrossRef]

85. Sritharan, T.; Savitri, K.N.; Jayasinghe, L.; Araya, H.; Fujimoto, Y. Isocoumarins and Dihydroisocoumarins from the endophytic fungus Biscogniauxia capnodes isolated from the fruits of Averrhoa carambola. Nat. Prod. Commun. 2019, 14. [CrossRef]

86. Henriques, J.; Nóbrega, F.; Sousa, E.; Lima, A. Analysis of the genetic diversity and phylogenetic relationships of Biscogniauxia mediterranea isolates associated with cork oak. Phytoparasitica 2016, 44, 19-34. [CrossRef]

87. Juybari, H.Z.; Tajick Ghanbary, M.A.; Rahimian, H.; Karimi, K.; Arzanlou, M. Seasonal, tissue and age influences on frequency and biodiversity of endophytis fungi of Citrus sinensis in Iran. For. Pathol. 2019, e12559. [CrossRef]

88. Mirabolfathy, M.; Groenewald, J.Z.; Crous, P.W. The occurrence of charcoal disease caused by Biscogniauxia mediterranea on chestnut-leaved oak (Quercus castaneifolia) in the Golestan Forests of Iran. Plant Dis. 2011, 95, 876. [CrossRef]

89. Mirabolfathy, M.; Ju, Y.-M.; Hsieh, H.-M.; Rogers, J.D. Obolarina persica sp. nov., associated with dying Quercus in Iran. Mycoscience 2013, 54, 315-320. [CrossRef]

90. Rostamian, M.; Kavosi, M.R.; Bazgir, E.; Babanezhad, M. First report of Biscogniauxia mediterranea causing canker on wild almond (Amygdalus scoparia). Australas. Plant Dis. Notes 2016, 11, 30. [CrossRef]

91. Voglmayr, H.; Jaklitsch, W.M. Stilbocrea walteri sp. nov., an unusual species of Bionectriaceae. Mycol. Prog. 2019, 18, 91-105. [CrossRef] [PubMed]

92. Kinsey, G.C. Phoma pinodella. [Descriptions of Fungi and Bacteria]. IMI Descr. Fungi Bact. 2002, 151, 1505.

93. Ramos, A.P.; Talhinhas, P.; Sreenivasaprasad, S.; Oliveira, H. Characterization of Colletotrichum gloeosporioides, as the main causal agent of citrus anthracnose, and C. karstii as species preferentially associated with lemon twig dieback in Portugal. Phytoparasitica 2016, 44, 549-561. [CrossRef]

94. Sutton, B.C. The genus Glomerella and its anamorph Colletotrichum. In Colletotrichum: Biology, Pathology and Control; Bailey, J.A., Jeger, M.J., Eds.; CAB Int.: Wallingford, UK, 1992; pp. 1-26.

95. Damm, U.; Cannon, P.F.; Woudenberg, J.H.C.; Johnston, P.R.; Weir, B.S.; Tan, Y.P.; Shivas, R.G.; Crous, P.W. The Colletotrichum boninense species complex. Stud. Mycol. 2012, 73, 1-36. [CrossRef] [PubMed]

96. Lijuan, P.; Youlian, Y.; Kevin, D.H.; Bahkali, A.H.; Zuoyi, L. Colletotrichum species on Citrus leaves in Guizhou and Yunnan provinces, China. Cryptogam. Mycol. 2012, 33, 267-283. [CrossRef]

97. Taheri, H.; Javan-Nikkhah, M.; Elahinia, S.A.; Khodaparast, S.A.; Golmohammadi, G. Species of Colletotrichum associated with citrus trees in Iran. Mycol. Iran. 2016, 3, 1-14.

98. Sutton, B.C. The Coelomycetes. Fungi Imperfecti with Pycnidia, Acerouli and Stromata; Commonwealth Mycological Institute: Kew, UK, 1980.

99. Petrini, O.; Fisher, P.J. A comparative study of fungal endophytes in xylem and whole stem of Pinus sylvestris and Fagus sylvatica. Trans. Br. Mycol. Soc. 1988, 91, 233-238. [CrossRef]

100. Hormazabal, E.; Piontelli, E. Endophytic fungi from Chilean native gymnosperms: Antimicrobial activity against human and phytopathogenic fungi. World J. Microbiol. Biotechnol. 2009, 25, 813-819. [CrossRef]

101. Carlucci, A.; Lops, F.; Cibelli, F.; Raimondo, M.L. Phaeoacremonium species associated with olive wilt and decline in southern Italy. Eur. J. Plant Pathol. 2015, 141, 717-729. [CrossRef]

102. Abdollahi Aghdam, S.; Fotouhifar, K.-B. New reports of endophytic fungi associated with cherry (Prunus avium) and sour cherry (Prunus cerasus) trees in Iran. Mycol. Iran. 2016, 3, 75-85.

103. Ghobad-Nejhad, M.; Meyn, R.; Langer, E. Endophytic fungi isolated from healthy and declining Persian oak (Quercus brantii) in western Iran. Nova Hedwig. 2018, 107, 273-290. [CrossRef]

104. Pavlic, D.; Slippers, B.; Coutinho, T.A.; Wingfield, M.J. Botryosphaeriaceae occurring on native Syzygium cordatum in South Africa and their potential threat to Eucalyptus. Plant Pathol. 2007, 56, 624-636. [CrossRef]

105. Mohali, S.; Slippers, B.; Wingfield, M.J. Pathogenicity of seven species of the Botryosphaeriaceae on Eucalyptus clones in Venezuela. Australas. Plant Pathol. 2009, 38, 135-140. [CrossRef] 
106. Úrbez-Torres, J.R.; Leavitt, G.M.; Guerrero, J.C.; Guevara, J.; Gubler, W.D. Identification and pathogenicity of Lasiodiplodia theobromae and Diplodia seriata, the causal agents of bot canker disease of grapevines in Mexico. Plant Dis. 2008, 92, 519-529. [CrossRef]

107. Michailides, T.J.; Morgan, D.P.; Felts, D. First report of Botryosphaeria rhodina causing shoot blight of pistachio in California. Plant Dis. 2002, 86, 1273. [CrossRef] [PubMed]

108. Phillips, A.J.L. The Botryosphaeria Site. 2006. Available online: http://www.crem.fct.unl.pt/botryosphaeria_ site (accessed on 29 November 2016).

109. Crous, P.W.; Gams, W.; Wingfield, M.J.; Van Wyk, P.S. Phaeoacremonium gen. nov. associated with wilt and decline diseases of woody hosts and human infections. Mycologia 1996, 88, 786-796. [CrossRef]

110. Boerema, G.H.; Gruyter, J.D.; Noordeloos, M.E.; Hamers, M.E.C. Phoma Identification Manual; CABI Publishing: Wallingford, UK, 2004.

111. Cai, L.; Hyde, K.D.; Taylor, P.W.J.; Weir, B.S.; Waller, J.; Abang, M.M.; Zhang, J.Z.; Yang, Y.L.; Phoulivong, S.; Liu, Z.Y.; et al. A polyphasic approach for studying Colletotrichum. Fungal Divers. 2009, 39, 183-204.

112. Aveskamp, M.M.; Verkley, G.J.M.; Gruyter, J.D.; Murace, M.A.; Perelló, A.; Woudenberg, H.C.; Groenewald, J.Z.; Crous, P.W. DNA phylogeny reveals polyphyly of Phoma section Peyronellaea and multiple taxonomic novelties. Mycologia 2009, 101, 363-382. [CrossRef]

113. Aveskamp, M.M.; de Gruyter, J.; Woudenberg, J.H.C.; Verkley, G.J.M.; Crous, P.W. Highlights of the Didymellaceae: A polyphasic approach to characterise Phoma and related pleosporalean genera. Stud. Mycol. 2010, 65, 1-60. [CrossRef]

114. Weir, B.S.; Johnston, P.R.; Damm, U. The Colletotrichum gloeosporioides species complex. Stud. Mycol. 2012, 73, 115-180. [CrossRef]

115. White, T.J.; Bruns, T.; Lee, S.; Taylor, J. Amplification and direct sequencing of fungal ribosomal RNA genes for phylogenetics. In PCR Protocols: A Guide to Methods and Applications; Innis, M.A., Gelfand, D.H., Snisky, J.J., White, T.J., Eds.; Academic: San Diego, CA, USA, 1990; pp. 315-322.

116. Carbone, I.; Kohn, L.M. A method for designing primer sets for speciation studies in filamentous ascomycetes. Mycologia 1999, 91, 553-556. [CrossRef]

117. Glass, N.L.; Donaldson, G.C. Development of primer sets designed for use with the PCR to amplify conserved genes from filamentous ascomycetes. Appl. Environ. Microbiol. 1995, 61, 1323-1330. [CrossRef] [PubMed]

118. O'Donnell, K.; Cigelnik, E. Two divergent intragenomic rDNA ITS2 types within a monophyletic lineage of the fungus Fusarium are nonorthologous. Mol. Phylogenet. Evol. 1997, 7, 103-116. [CrossRef]

119. Katoh, K.; Toh, H. Parallelization of the MAFFT multiple sequence alignment program. Bioinformatics 2010, 26, 1899-1900. [CrossRef] [PubMed]

120. Rambaut, A. Sequence Alignment Editor. Version 2.0; University of Oxford: Oxford, UK, 2002.

121. Swofford, D.L. PAUP* 4.0: Phylogenetic Analysis Using Parsimony ( ${ }^{*}$ and Other Methods); Sinauer Associates: Sunderland, MA, USA, 2003.

122. Kumar, S.; Stecher, G.; Tamura, K. MEGA7: Molecular Evolutionary Genetics Analysis version 7.0 for bigger datasets. Mol. Biol. Evol. 2016, 33, 1870-1874. [CrossRef] [PubMed]

123. Darriba, D.; Taboada, G.L.; Doallo, R.; Posada, D. jModelTest 2: More models, new heuristics and parallel computing. Nat. Methods 2012, 9, 772. [CrossRef]

(C) 2020 by the authors. Licensee MDPI, Basel, Switzerland. This article is an open access article distributed under the terms and conditions of the Creative Commons Attribution (CC BY) license (http://creativecommons.org/licenses/by/4.0/). 